\title{
ŠTO JE BOLII PREDIKTOR USPJEHA IZ MATEMATIKE I FIZIKE - STAVOVI PREMA MATEMATICI ILI KAPACIITET RADNOG PAMĆENJA
}

\author{
Josip Novak \\ Nacionalni centar za vanjsko vrednovanje obrazovanja, Zagreb, Republika Hrvatska \\ Predrag Brođanac \\ V. gimnazija, Zagreb, Republika Hrvatska
}

\begin{abstract}
Sažetak
U istraživanjima se pokazalo kako su stavovi prema matematici značajan prediktor različitih ishoda u matematici, poput angažmana ili postignuća, ali i kasnije akademske izvedbe u matematici i prirodnim predmetima te uspjeha i upornosti u učenju matematike. Međutim, na hrvatskim uzorcima stavovi prema matematici i njihov odnos s uspjehom iz Matematike i Fizike slabo je istražen, kao i uloga radnog pamćenja u navedenome odnosu. Radno pamćenje snažno je povezano s izvedbom u zadacima iz matematike i stoga je od praktične koristi odrediti kakvu ulogu ima u odnosu stavova prema matematici i uspjeha iz Matematike i Fizike. Istraživanje je provedeno na prigodnom uzorku od 178 učenika V. gimnazije u Zagrebu, u kojemu je podjednak omjer spolova. Rezultati provedenog istraživanja pokazuju kako radno pamćenje i Percipirana korisnost matematike nisu značajni prediktori uspjeha iz Matematike i Fizike kada su u regresijsku jednadžbu uključeni i faceti stavova prema matematici, Naklonost prema matematici i Matematičko samopoimanje. Konačan model i zabilježeni medijacijski efekti imaju praktične implikacije i upućuju na daljnja istraživanja odnosa tih konstrukata.
\end{abstract}

Ključne riječi: stavovi prema matematici, radno pamćenje, školski uspjeh

\section{UvoD}

\section{Stavovi prema matematici}

Sve se više prepoznaje da, uz kognitivne faktore, afektivni faktori također imaju ključnu ulogu u podučavanju i učenju matematike (Majeed, Darmawan i Lynch, 2013). McLeod (1992) je pionir nove faze proučavanja afekata u obrazovanju iz matematike, odnosno reprezentirao je afektivnu komponentu kao tri subdomene: emocije, stavove i vjerovanja. U prijašnjim istraživanjima (npr. Aiken i Dreger, 1961; Antonnen, 1969; Biggs, 1959; Dutton, 1954; Neale, 1969; Poffenberger i Norton, 1959) termin „stavovi“ korišten je kao sveobuhvatan. Bilo je više pokušaja definiranja stavova prema matematici kao konstrukta. Haladyna, Shaughnessy i Shaughnessy (1983) definiraju ga kao pozitivnu ili negativnuemocionalnu dispoziciju prema matematici. Eshun (2004, str. 2) ga definira kao „dispoziciju prema aspektu matematike koji je usvojen od strane pojedinca kroz njegova vjerovanja i iskustva, ali koja mogu biti promijenjena." Leder i Grootenboer (2005) sugeriraju da su stavovi srednja kategorija, odnosno stabilniji su od osjećaja, ali nisu stabilni kao vjerovanja i/ili vrijednosti. 


\section{Stavovi prema matematici i postignuće iz matematike i prirodnih predmeta}

Učenički stavovi razvijeni su tijekom dužeg vremenskog razdoblja i imaju značajan utjecaj na njihov učinkovit angažman, sudjelovanje i postignuće u matematici. Oni nisu urođeni, već su rezultat iskustva i stoga mogu biti promijenjeni. Jedno istraživanje (Shashaani, 1995) iznjedrilo je pozitivnu korelaciju između stavova prema matematici i iskustava s matematikom, dok drugo (Gallagher i De Lisi, 1994) sugerira pozitivan odnos između izvedbe na standardiziranom testu iz matematike i pozitivnih stavova prema matematici. Ma i Kishor (1997) proveli su meta-analizu na uzorku od 113 istraživanja kako bi utvrdili jačinu odnosa postignuća iz matematike i stavova prema matematici te su dobili podatak koji ukazuje na slabiju povezanost u osnovnoj, ali izraženiju u srednjoj školi. Prema istraživanju koje su proveli Reynolds i Walberg (1992a) pokazalo se da su stavovi prema matematici i prirodnim predmetima prediktori kasnije akademske izvedbe u matematici i prirodnim predmetima te uspjeha i upornosti u učenju matematike.Terwilliger i Titus (1995) te Ma (2003) pokazali su da uspostavljeni negativni stavovi prema matematici jačaju tijekom vremena.

\section{Radno pamćenje i matematika}

Istraživanja u psihologiji obrazovanja zabilježila su snažnu povezanost između izvedbe u matematici i mjera radnog pamćenja. Primjerice, Hutton i Towse (2001) izvješćuju o korelaciji od .45 između zadataka pamćenja raspona brojeva i izvedbe na matematičkim testovima. Swanson i Beebe-Frankenberger (2004) dobili su korelaciju od .54 između radnog pamćenja i rješavanja problema iz matematike, a LeBlanc i Weber-Russell (1996) utvrdili su da radno pamćenje objašnjava do $57 \%$ varijance rješavanja problemskih zadataka iz matematike kod djece. U jednoj meta-analizi (Friso-van den Bos, van der Ven, Kroesbergen i van Luit, 2013) utvrđeno je da su svi aspekti radnog pamćenja povezani s matematičkim sposobnostima, dok je najizraženiji prediktor verbalno ažuriranje. Jedan aspekt tog odnosa uključuje manipuliranje brojčanim vrijednostima, a drugi aspekt ispituje ukupan broj koraka potrebnih za rješavanje problema (Ashcraft i Krause, 2007). Utvrđeno je da je radno pamćenje uključenije u rješavanje problema s porastom brojeva (operanada) u matematičkom problemu. Primjerice, odgovor na $6+7$ ili $9 \times 6$ bit će sporiji i manje precizan nego na 2+3 ili $4 \times 5$ (pogledati Zbrodoff i Logan, 2005, prema Ashcraft i Krause, 2007). Međutim, to je vjerojatno slučaj dijelom zbog pohranjivanja mentalnih reprezentacija aritmetičkih činjenica u dugoročnom pamćenju i inverznog odnosa između kompleksnosti problema i čestine njegovog pojavljivanja. Drugi dio efekta odnosi se na sve veću tendenciju da se probleme s većim operandima rješava procesima koji ne uključuju dosjećanje, primjerice brojanjem, rekonstrukcijom iz drugih problema ili ostalih strategija (pogledati Campbell i Xue, 2001; LeFevre, Sadesky i Bisanz, 1996, prema Ashcraft i Krause, 2007). Prema tome, potonji bi procesi bili sporiji i češće dovodili do pogrešaka za razliku od onih koji uključuju dosjećanje, posebice kod kompleksnijih problema, što je potvrđeno $u$ istraživanjima (Seyler, Kirk i Ashcraft, 2003). Što se tiče odnosa broja koraka potrebnih za rješavanje problema i radnog pamćenja, u jednom je istraživanju (Ashcraft i Kirk, 2001) pretpostavka bila da će operacije prenošenja u zbrajanju zahtijevati dodatno procesiranje u radnom pamćenju jer se prenošenje odnosi na još jedan korak u sekvenci procesiranja. Rezultat je ukazao na sporije rješavanje i veću količinu pogrešaka kod problema koji uključuju prenošenje. Prema tome, procesiranje u radnom pamćenju nužno je prilikom aritmetičke i matematičke izvedbe kad god je u pitanju procesiranje koje ne uključuje dosjećanje (Ashcraft i Krause, 2007). Što se tiče vrste radnog pamćenja uključenog u matematičku kogniciju, pokazalo se da se djeca predškolske dobi više oslanjaju na vizuospacijalno radno pamćenje (Holmes i Adams, 2006), ali to traje samo do prvog razreda osnovne škole. $S$ druge strane, verbalno je radno pamćenje uključeno u matematičko računanje, posebno tijekom kompleksne mentalne aritmetike. Primjerice, Imbo, Vandierendonck i Vergauwe (2007) izvješćuju da je verbalno radno pamćenje uključeno u kompleksno računanje kada postoji potreba za operacijom posuđivanja, dok Wilson i Swanson 
Josip Novak, Predrag Brođanac

(2001) zaključuju da je verbalno radno pamćenje bolji prediktor matematičkog računanja od vizuospacijalnog radnog pamćenja. Istraživanje Bull i Scerif (2001) pokazalo je da inhibitorna funkcija centralnog izvršitelja ima važnu ulogu u matematičkim sposobnostima kod djece, dok su Bull i Lee (2014) dobili podatak da je funkcija ažuriranja centralnog izvršitelja značajan prediktor postignuća iz matematike u svim dobnim skupinama.

\section{Svrha istraživanja}

Arambašić, Vlahović-Štetić i Severinac (2005) te Pavlin-Bernardić, Vlahović-Štetić, Rovan i Arambašić (2009) ispitivale su stavove učenika viših razreda osnovnih škola i gimnazijalaca prema matematici. U navedenim istraživanjima nije mjeren utjecaj radnog pamćenja, čija bitna uloga u postignuću iz matematike ima snažnu empirijsku potporu. Stoga je svrha ovog istraživanja utvrditi odnos stavova prema matematici, radnog pamćenja te uspjeha iz Matematike i Fizike, kao predmeta s istaknutom matematičkom komponentom, pri čemu je uspjeh iz Matematike i Fizike zavisna varijabla.

\section{Hipoteze:}

H1: Kapacitet radnog pamćenja statistički je značajan pozitivan prediktor uspjeha iz Matematike i Fizike kada su svi prediktori uvršteni u model.

H2: Subskale stavova prema matematici statistički su značajni pozitivni prediktori uspjeha iz Matematike i Fizike kada su svi prediktori uvršteni u model.

H3: Kapacitet radnog pamćenja ima veću prediktivnu snagu uspjeha iz Matematike i Fizike od subskala stavova prema matematici kada su svi prediktori uvršteni u model.

\section{Metoda $^{1}$}

\section{Sudionici}

$\mathrm{U}$ istraživanju je sudjelovalo 178 učenika od drugog do četvrtog razreda $\mathrm{V}$. gimnazije u Zagrebu, od kojih je 89 (50\%) bilo ženskog spola. Raspon dobi bio im je od 15 do 18 godina (M $=16.74, \mathrm{SD}=.88)$. Uzorak je sačinjavalo $54(30,30 \%)$ učenika drugog razreda, $68(38,20 \%)$ trećeg razreda i $56(31,50 \%)$ četvrtog razreda.

\section{Instrumenti}

Stavovi prema matematici mjereni su skraćenom verzijom Skale stavova prema matematici Fenneme i Sherman (Matilla, 2005, prema Metsämuuronen, 2012). Faktorskom analizom na finskom uzorku dobiven je model koji se sastoji od tri subskale, Naklonosti prema matematici, Matematičkog samopoimanja te Percipirane korisnosti matematike. Sudionici daju odgovore na Likertovoj skali od 1 (,U potpunosti se ne slažem.") do 5 („U potpunosti se slažem. “). Postojale su teškoće u primjeni prvotne verzije zbog međukulturalnih razlika, ali takav adaptirani model moguće je koristiti i u ostatku Europe (Metsämuuronen, 2012). Koeficijent unutarnje konzistencije u tom je istraživanju bio zadovoljavajući $(\alpha=.85)$.

Postignuće iz Matematike i Fizike mjereno je prosjekom ocjena iz Matematike i Fizike na kraju protekle školske godine. Uz ocjenu iz Matematike korištena je i ocjena iz Fizike, s obzirom da se radi o predmetu s izraženom matematičkom komponentom.

\footnotetext{
1 Operacionalizacija kapaciteta radnog pamćenja i postupak jednaki su kao u Novak (2018).
} 
Kapacitet radnog pamćenja mjeren je pomoću baterije testova koje su osmislili Stone i Towse (2015). Verbalno radno pamćenje mjereno je operacijskim rasponom i rasponom radnog pamćenja pri čitanju, dok je spacijalno mjereno simetrijskim i rotacijskim rasponom. Prije prikaza čestica za upamćivanje sudionicima je prezentirana pisana uputa prije svakog zadatka kompleksnog raspona, nakon koje je prikazan znak X pet sekundi na mjestu na kojem će biti prikazane čestice. Svaka je čestica prikazana dvije sekunde. U svakom od kompleksnih raspona bilo je devet pokušaja, a svaki je pokušaj prikazan dva puta radi povećanja pouzdanosti.

Operacijski raspon sastoji se od ponovljenog ciklusa izmjene upamćivanja i procesiranja. $U$ ovoj verziji sudionicima su prikazani dvoznamenkasti cijeli brojevi koje treba upamtiti i dosjetiti ih se u prikazanom redoslijedu, tj. upisati na tipkovnici onim redoslijedom kojim su prikazani. Neposredno nakon svakog prikaza broja slijedi faza procesiranja, koja uključuje prikaz jednostavne matematičke operacije poput „6+7=10“, a sudionik treba označiti je li odgovor točan (pogledati Slika 1). Brojevi i operacije nasumično su generirani za svaki pokušaj. Za svaku operaciju postoji vjerojatnost od $50 \%$ da je odgovor točan, a vjerojatnost da se radi o operaciji zbrajanja, oduzimanja, množenja ili dijeljenja je $25 \%$ za svaku od navedenih.

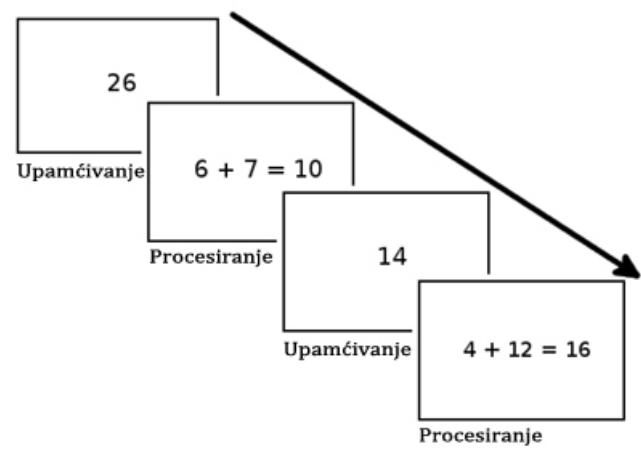

Slika 1. Primjeri faza upamćivanja i procesiranja za operacijski raspon radnog pamćenja

Raspon radnog pamćenja pri čitanju razlikuje se od operacijskog raspona u elementu procesiranja. Umjesto matematičke operacije sudionicima je prezentirana rečenica, a zadatak je bio odlučiti je li smislena, pri čemu je vjerojatnost pojavljivanja smislene i besmislene rečenice $50 \%$ za svaku. Rečenice su unaprijed definirane i osmišljene od strane istraživača, duljine su od tri do osam riječi, a svaka je korištena samo jedanput. Sudionici također pamte i upisuju brojeve onim redoslijedom kojim su prikazani.

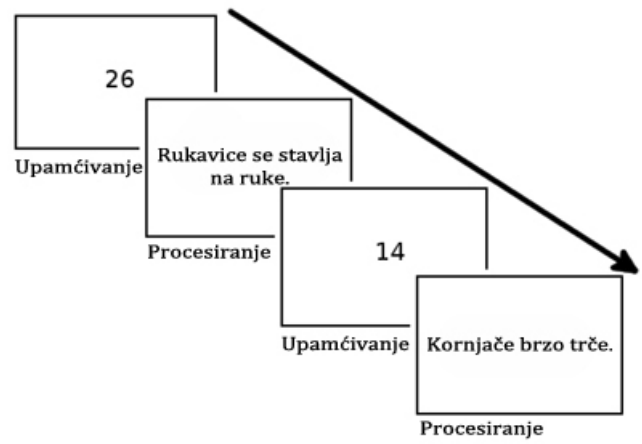

Slika 2. Primjeri faza upamćivanja i procesiranja za raspon radnog pamćenja pri čitanju 
Simetrijski raspon zahtijeva od sudionika pamćenje redoslijeda označenih polja rešetke veličine $4 \times 4$. Nakon svakog prikaza rešetke sudionicima je prikazan obrazac veličine $8 \times 8$ za koji trebaju ocijeniti je li simetričan s obzirom na vertikalnu os. Nakon svih pokušaja koji uključuju upamćivanje i procesiranje, sudionici trebaju klikati na polja rešetke $4 \times 4$ i označiti kojim su redoslijedom polja bila označena. Kada označe polje, ono postaje plavo pa sudionici mogu pratiti svoje odgovore.

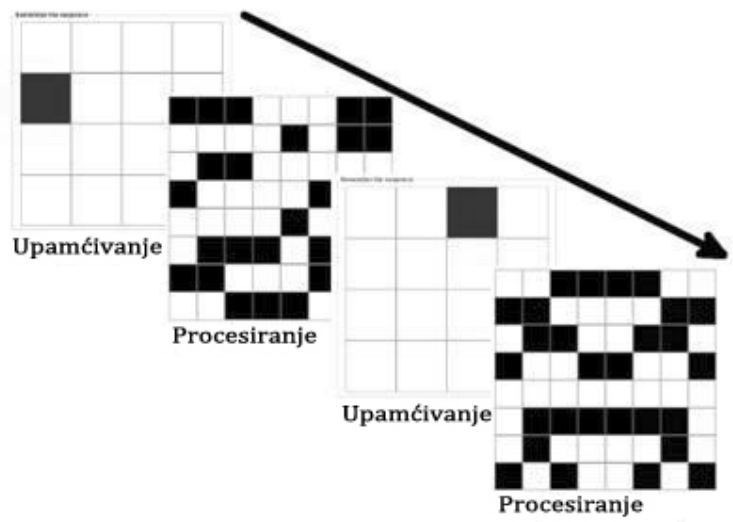

Slika 3. Primjeri faza upamćivanja i procesiranja za simetrijski raspon

Rotacijski raspon uključuje upamćivanje redoslijeda strjelica koje se razlikuju u dvije karakteristike: duljini (dugačka ili kratka) i kutu rotacije (0ㅇ, 45ㅇ, 90ㅇ, 135ㅇ, 180, 225, 270ㅇ, 315). Nakon prikaza strjelica, u fazi procesiranja, sudionicima su prikazana slova (F, G i R), standardne ili zrcalne orijentacije, koja su također rotirana pod različitim kutovima, a orijentaciju sudionici trebaju procijeniti pritiskom gumba koji predstavljaju orijentacije normalno/zrcalno na tipkovnici.

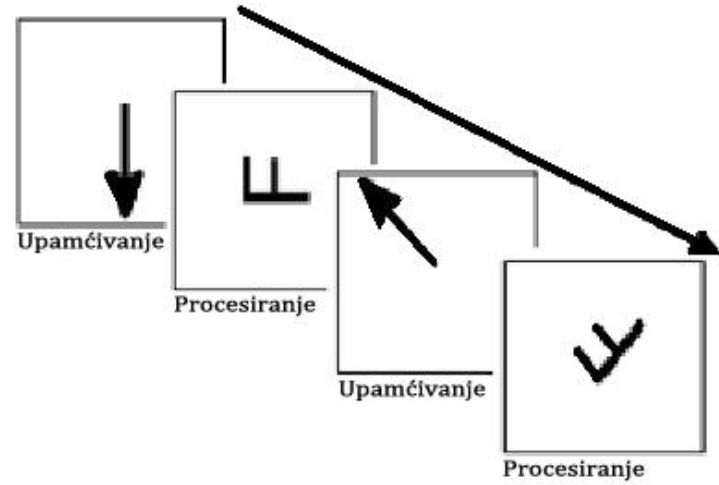

Slika 4. Primjeri faza upamćivanja i procesiranja za rotacijski raspon

\section{Postupak}

Istraživanje je provedeno na početku školske godine. Uzorak je prigodan, a razredna odjeljenja odabrana su po slučaju. Prije početka prikupljanja sudionicima je objašnjeno da se 
radi o istraživanju nekih aspekata mišljenja i ponašanja, nakon čega su im dane upute. Sudionici su ispunjavali upitnik i rješavali zadatke kompleksnog raspona na računalima u informatičkim učionicama, u skupinama od polovice razrednog odjeljenja. U svakoj je skupini prikupljanje podataka trajalo do dva školska sata. Obrada podataka izvršena je u statističkom programu $R$ (R Core Team, 2019). Od paketa za R korišteni su psych (Revelle, 2019) za deskriptivnu analizu i faktorsku analizu, MVN (Korkmaz, Goksuluk i Zararsiz, 2014) za testiranje multivarijatnog normaliteta, Imtest (Hothorn, Zeileis, Farebrother i sur., 2018) za testiranje preduvjeta za provedbu regresijske analize, estimatr (Blair, Cooper, Coppock i sur., 2019) za provedbu robusne regresijske analize te pwr (Champely, 2018) za izračun statističke snage.

\section{ReZULtATI}

S obzirom da je instrument kojim su mjereni stavovi prema matematici preveden, prije obrade podataka provedena je faktorska analiza. Korištena je konfirmatorna faktorska analiza s tri predodređena faktora na matrici kovarijanci uz metodu najveće vjerojatnosti i kosokutnu rotaciju. Zadržane su isključivo čestice sa saturacijama iznad .5.

Tablica 1. Faktorska struktura stavova prema matematici

\begin{tabular}{|l|c|c|c|}
\hline \multirow{2}{*}{ Čestica } & \multicolumn{2}{|c|}{ Faktor } \\
\cline { 2 - 4 } & $\begin{array}{c}\text { Naklonost } \\
\text { prema } \\
\text { matematici }\end{array}$ & $\begin{array}{c}\text { Matematičko } \\
\text { samopoimanje }\end{array}$ & $\begin{array}{c}\text { Percipirana } \\
\text { korisnost } \\
\text { matematike }\end{array}$ \\
\hline $\begin{array}{l}\text { Obično imamo zanimljive zadatke na nastavi } \\
\text { matematike. }\end{array}$ & 1.051 & & \\
\hline Volim učiti matematiku. & 1.035 & & \\
\hline Matematika je jedan od mojih omiljenih predmeta. & .917 & & \\
\hline Matematika je dosadan predmet._r & .581 & & \\
\hline Volim lekcije iz matematike. & & .961 & \\
\hline Mislim da sam dobar u matematici. & & .711 & \\
\hline Matematika je lagan predmet. & & & .529 \\
\hline Mnogo stvari u matematici je teško._r & & & .973 \\
\hline Mislim da su matematičke vještine važne. & & & \\
\hline $\begin{array}{l}\text { Matematičko znanje i vještine važni su u } \\
\text { svakodnevnom životu. }\end{array}$ & & & \\
\hline Trebam matematiku za ono što ću studirati. & & & \\
\hline
\end{tabular}

Iz Tablice 1. može se vidjeti kako je faktorska struktura stavova prema matematici valjana, ali se razlikuje po broju čestica od one kakvu je dobio Mattila (2005; prema Metsämuuronen, 2012) na finskom uzorku učenika prvog razreda srednje škole veličine $N=4511$. Izbačene su sljedeće čestice kako bi konvergiranje bilo moguće uz što veću količinu objašnjene varijance i što bolje indekse pristajanja: „Mogu se nositi i s teškim zadacima iz matematike.”, „Za mene je nemoguće dobiti dobre rezultate iz matematike.", „Neću trebati gradivo koje sam naučio iz matematike u budućnosti." te "Smatram da ću trebati znanje i vještine iz matematike u poslu." 
Josip Novak, Predrag Brođanac ŠTO JE BOLI PREDIKTOR USPJEHA IZ MATEMATIKE I FIZIKE...

Navedena faktorska struktura objašnjava $56,00 \%$ varijance. Tucker-Lewisov indeks iznosi .946, RMSEA .076, a RMSR .06, što je zadovoljavajuće. Prema tome, ovaj instrument može biti korišten i na hrvatskom uzorku, ukoliko su izbačene navedene čestice.

Tablica 2. Deskriptivni podaci za ukupne rezultate i pojedine subskale korištenih varijabli

\begin{tabular}{|l|c|c|c|c|c|c|c|c|c|c|}
\hline Varijabla & $\mathrm{M}$ & $\mathrm{SD}$ & $\mathrm{Med}$ & $\mathrm{IQR}$ & $\mathrm{TR}$ & $\mathrm{PR}$ & $\alpha / \hat{\mathrm{r}}$ & $\mathrm{IA}$ & $\mathrm{IK}$ & $\mathrm{S}-\mathrm{W}$ \\
\hline $\begin{array}{l}\text { Stavovi prema } \\
\text { matematici }\end{array}$ & 36.29 & 8.04 & 36 & 9.75 & $11-55$ & $17-55$ & .83 & .02 & -.26 & .99 \\
\hline $\begin{array}{l}\text { Matematičko } \\
\text { samopoimanje }\end{array}$ & 11.11 & 3.74 & 11 & 5.75 & $4-20$ & $4-20$ & .74 & .29 & -.55 & $.98^{* * *}$ \\
\hline $\begin{array}{l}\text { Naklonost prema } \\
\text { matematici }\end{array}$ & 14.03 & 4.20 & 14 & 6 & $4-20$ & $4-20$ & .83 & -.50 & -.54 & $.95^{* * *}$ \\
\hline $\begin{array}{l}\text { Percipirana } \\
\text { korisnost } \\
\text { matematike }\end{array}$ & 11.15 & 2.90 & 12 & 4 & $3-15$ & $3-15$ & .76 & -.72 & -.19 & $.93^{* * *}$ \\
\hline $\begin{array}{l}\text { Kapacitet radnog } \\
\text { pamćenja }\end{array}$ & 3.50 & 1.19 & 3.3 & 1.7 & $0-9$ & $.67-7.7$ & .24 & .44 & .05 & $.97^{* * *}$ \\
\hline $\begin{array}{l}\text { Uspjeh iz } \\
\text { Matematike i Fizike }\end{array}$ & 4.00 & .79 & 4.0 & 1 & $2-5$ & $2-5$ & - & -.45 & -.66 & $.92^{* * *}$ \\
\hline
\end{tabular}

Legenda:

$* * * p<.001$

$\mathrm{M}$ - aritmetička sredina

SD - standardna devijacija

Med - medijan

IQR - interkvartilno raspršenje

TR - teorijski raspon

$\mathrm{PR}$ - postignuti raspon

$\alpha / \hat{r}$ - Cronbachova alfa/prosječna interkorelacija u slučaju kapaciteta radnog pamćenja

IA - indeks asimetričnosti

IK - indeks kurtotičnosti

S-W -Shapiro-Wilkov test

Iz Tablice 2. može se vidjeti kako su Cronbachove alfe cjelokupne skale stavova prema matematici kao i Cronbachove alfe pojedinih subskala zadovoljavajuće. Unutarnja konzistencija kapaciteta radnog pamćenja određena je prosječnom interkorelacijom čestica. Kako bi unutarnja konzistencija bila zadovoljavajuća, izbačen je Operacijski raspon radnog pamćenja. Briggs i Cheek (1986) kao optimalan navode raspon prosječne interkorelacije čestica od .2 do .4., a iz tablice se može vidjeti da je vrijednost unutar preporučenoga raspona. Normalitet distribucija provjeren je indeksom asimetričnosti i kurtotičnosti, usporedbom aritmetičkih sredina s medijanima, grafičkom metodom, odnosno uvidom u histograme te Shapiro-Wilkovim testom zbog njegove statističke snage (Yap i Sim, 2011). Na temelju uvida u histograme može se zaključiti kako postoji odudaranje od normaliteta kod svih distribucija osim cjelokupne skale stavova prema matematici, iako su indeksi asimetričnosti i kurtotičnosti blizu nule. Također, Roystonov $\mathrm{H}$ test ukazuje na narušen multivarijatni normalitet $(H=96.92, p<.001)$. 
Tablica 3. Matrica korelacija za ukupne rezultate i pojedine subskale korištenih varijabli

\begin{tabular}{|l|c|c|c|c|c|c|}
\hline Varijabla & 1. & 2. & 3. & 4. & 5. & 6. \\
\hline 1. Stavovi prema matematici & 1.00 & & & & & \\
\hline 2. Matematičko samopoimanje & $.67^{* * *}$ & 1.00 & & & & \\
\hline 3. Naklonost prema matematici & $.83^{* * *}$ & $.26 * * *$ & 1.00 & & & \\
\hline 4. Percipirana korisnost matematike & $.71^{* * *}$ & $.19^{* *}$ & $.50^{* * *}$ & 1.00 & & \\
\hline 5. Kapacitet radnog pamćenja & $.29^{* * *}$ & $.26^{* * *}$ & $.18^{*}$ & $.20^{* *}$ & 1.00 & \\
\hline 6. Uspjeh iz Matematike i Fizike & $.46^{* * *}$ & $.30^{* * *}$ & $.41^{* * *}$ & $.29 * * *$ & $.18^{* *}$ & 1.00 \\
\hline
\end{tabular}

Napomena: ${ }^{*} p<.05,{ }^{* *} p<.01,{ }^{* * *} p<.001$

Iz Tablice 3. može se vidjeti kako su svi Pearsonovi $r$ koeficijenti korelacije statistički značajni. Između stavova prema matematici i uspjeha iz Matematike i Fizike postoji pozitivna korelacija $(r=.46, p<.001)$. Što se tiče povezanosti subskala stavova prema matematici s uspjehom iz Matematike i Fizike, Matematičko samopoimanje statistički je značajno povezano $s$ uspjehom iz Matematike i Fizike $(r=.30, p<.001)$ kao i Naklonost prema matematici $(r=.41$, $p<.001)$ te Percipirana korisnost matematike $(r=.29, p<.001)$. Između stavova prema matematici i kapaciteta radnog pamćenja postoji blaga pozitivna korelacija $(r=.29, p<.001)$. Od subskala stavova prema matematici Matematičko samopoimanje blago je pozitivno povezano $s$ kapacitetom radnog pamćenja $(r=.26, p<.001)$ kao i Naklonost prema matematici $(r=.18, p<.05)$ te Percipirana korisnost matematike $(r=.20, p<.01)$.

S obzirom na to da su subskale stavova prema matematici međusobno blago do umjereno povezane, multikolinearnost nije problem u ovom modelu. Međutim, Breusch-Paganov test ukazuje na postojanje heteroscedasciteta $[B P=20(s s=4, p<.01)]$. Prema tome, korištena je robusna regresija uz metodu najmanjih kvadrata s Eicker-Huber-Whiteovim standardnim pogreškama, koje omogućavaju pristajanje modela s heteroscedastičkim rezidualima.

Tablica 4. Rezultati multiple robusne regresije s postignućem iz Matematike i Fizike kao zavisnom varijablom

Zavisna varijabla $=$ Postignuće iz Matematike i Fizike

\begin{tabular}{|c|c|c|c|c|c|c|}
\hline Model & $\beta$ & $\mathrm{t}$ & $\mathrm{p}$ & $\mathrm{R}$ & $\mathrm{R}^{2}$ & $\mathrm{~F}$ \\
\hline Konstanta & - & 8.37 & .00 & \multirow{5}{*}{.47} & \multirow{5}{*}{.22} & \multirow{5}{*}{$13 * * *$} \\
\hline Kapacitet radnog pamćenja & .07 & .85 & .40 & & & \\
\hline Matematičko samopoimanje & $.24 * * *$ & 2.96 & .00 & & & \\
\hline Naklonost prema matematici & $.32 * * *$ & 3.96 & .00 & & & \\
\hline Percipirana korisnost matematike & .07 & .96 & .34 & & & \\
\hline
\end{tabular}

Napomena: ${ }^{*} p<.05,{ }^{* *} p<.01,{ }^{* * *} p<.001$

Dobiveni je model statistički značajan $F(4,173, p<.001)=13.00$ uz koeficijent multiple korelacije $R=.47$, odnosno $R^{2}=.22$. Što se tiče pojedinačnih prediktora, kapacitet radnog pamćenja nije statistički značajan prediktor kao ni Percipirana korisnost matematike. S obzirom da kapacitet radnog pamćenja i Percipirana korisnost matematike prestaju biti značajnim prediktorima kada su uključene subskale stavova prema matematici, a u statistički su značajnoj korelaciji s uspjehom iz Matematike i Fizike, moguće je da su u modelu prisutni medijacijski 
efekti. Prema tome, strategijom kauzalnih koraka (Baron i Kenny, 1986) provjeren je medijacijski odnos Naklonosti prema matematici i Matematičkog samopoimanja između kapaciteta radnog pamćenja i uspjeha iz Matematike i Fizike te je utvrđeno kako su obje subskale zasebno medijator između kapaciteta radnog pamćenja i uspjeha iz Matematike i Fizike. U slučaju odnosa Percipirane korisnosti matematike i uspjeha iz Matematike i Fizike korištena je ista metoda. Pokazalo se da je Naklonost prema matematici medijator u navedenome odnosu, dok Matematičko samopoimanje nije. Matematičko samopoimanje $(\beta=.24, p<.001)$ i Naklonost prema matematici $(\beta=.32, p<.001)$ statistički su značajni pozitivni prediktori uspjeha iz Matematike i Fizike te objašnjavaju $22 \%$ varijance. Cohenov $\mathrm{f}^{2}$ iznosi .28, što ukazuje na srednju veličinu efekta, a statistička snaga iznosi 1.00 .

\section{RASPRAVA}

Rezultati provedenog istraživanja navode na nekoliko zaključaka. Kao prvo, prva i treća hipoteza odbačene su, dok je druga djelomično prihvaćena. Kapacitet radnog pamćenja u statistički je značajnoj pozitivnoj korelaciji s uspjehom iz Matematike i Fizike ( $r=.18, p<.01)$, što je u skladu s prijašnjim istraživanjima. Međutim, kada se u prediktivni model uvrsti stavove prema Matematici, kapacitet radnog pamćenja prestaje biti značajan prediktor. Stoga je prva hipoteza odbačena. Što se tiče druge hipoteze, pokazalo se kako su Matematičko samopoimanje i Naklonost prema matematici statistički značajni prediktori uspjeha iz Matematike i Fizike, dok Percipirana korisnost matematike to nije. Dakle, druga je hipoteza također djelomično potvrđena jer su samo određeni faceti stavova prema matematici značajni prediktori uspjeha iz Matematike i Fizike. Naposljetku, treća je hipoteza odbačena, odnosno, pokazalo se da su stavovi prema matematici bolji prediktor od kapaciteta radnog pamćenja.

Kao drugo, faktorska struktura skraćene verzije Skale stavova prema matematici Fenneme i Sherman (1976, prema Metsämuuronen, 2012) ima zadovoljavajuće indekse pristajanja. Prema tome, ovaj inventar moguće je koristiti i na hrvatskom uzorku ukoliko su izbačene određene čestice. Zanimljivo je što čestice „Neću trebati gradivo koje sam naučio iz matematike u budućnosti." te "Smatram da ću trebati znanje i vještine iz matematike u poslu." nisu bile zadržane u faktorskoj soluciji, dok su zadržane čestice "Mislim da su matematičke vještine važne.", „Matematičke vještine i znanje važni su u svakodnevnom životu." te „Trebam matematiku za ono što ću studirati.", koje se odnose na instrumentalnu važnost matematike u svakodnevnom životu i tijekom studiranja. Takav nalaz možda upućuje na različitost stava prema matematici hrvatskih učenika u odnosu na finske. Drugim riječima, moguće je da hrvatski učenici matematiku smatraju važnom općenito i za uspjeh u obrazovanju, ali ne i za profesionalnu budućnost. Ipak, s obzirom na veličinu uzorka potrebno je još istraživanja s većim i heterogenijim uzorkom kako bi se dodatno potvrdilo faktorsku strukturu ovog instrumenta u Hrvatskoj. Osim veličine uzorka, bitno je napomenuti da je uzorak prigodan, odnosno da je sačinjen od učenika prirodoslovno-matematičke gimnazije u kojoj su strogi kriteriji upisa i moguće je kako je u takvom uzorku struktura stavova prema matematici drugačija nego u ostalim školama. Uostalom, Matilla (2005, prema Metsämuuronen, 2012)provodio je faktorsku analizu na uzorku veličine $\mathrm{N}=4511$ u kojemu su svi učenici pohađali prvi razred srednje škole. Tuohilampi, Hannula, Laine i Metsämuuronen (2014) primijenili su navedeni instrument u longitudinalnom nacrtu mjereći stavove prema matematici u prvom i šestom razredu osnovne škole te u prvom razredu srednje škole na uzorku od 3502 učenika. Stoga ovu faktorsku strukturu treba interpretirati s oprezom.

Nadalje, deskriptivni podaci ukazuju na zadovoljavajuće koeficijente unutarnje konzistencije, ali i na odudaranje od normaliteta kod svih distribucija osim kod distribucije ukupnih stavova prema matematici. U slučaju kapaciteta radnog pamćenja, koji su iznosili $M=3.50$, $\mathrm{SD}=1.19$ za kapacitet radnog pamćenja, nalazi su u skladu s literaturom. Naime, Cowan (2010) 
je na temelju pregleda literature zaključio kako je tipičan kapacitet radnog pamćenja kod mladih odraslih osoba između 3 i 5 . Ipak, iako je utvrđeno da su svi aspekti radnog pamćenja povezani s matematičkim sposobnostima (Friso-van den Bos, van der Ven, Kroesbergen i van Luit, 2013), u ovom istraživanju nisu izmjereni svi aspekti radnog pamćenja, već samo kapaciteti. Moguće je da su određeni aspekti radnog pamćenja, poput funkcija centralnog izvršitelja statistički značajni prediktori i kada su aspekti stavova prema matematici uvršteni u regresijsku jednadžbu. Nadalje, u matrici korelacija može se vidjeti kako je kapacitet radnog pamćenja statistički značajno pozitivno povezan s Naklonošću prema matematici $(r=.18, p<.05)$, Matematičkim samopoimanjem $(r=.26, p<.001)$ te Percipiranom korisnošću matematike $(r=.20$, $\mathrm{p}<.01$ ). Pozitivan odnos radnog pamćenja i stavova prema matematici očekivan je. Primjerice, Jung i Reid (2009) na uzorku od 714 učenika u dobi od 12 do 14 godina došli su do nalaza o pozitivnoj povezanosti radnog pamćenja i stavova prema prirodoslovlju.

$\mathrm{U}$ multiploj regresijskoj analizi pokazalo se da su Naklonost prema matematici $(\beta=.32$, $p<.001)$ i Matematičko samopoimanje $(\beta=.24, p<.001)$ statistički značajni prediktori uspjeha iz Matematike i Fizike uz 22 \% objašnjene varijance. Također se pokazalo da kapacitet radnog pamćenja i Percipirana korisnost matematike nisu statistički značajni prediktori nakon uključivanja Naklonosti prema matematici i Matematičkog samopoimanja u model, unatoč značajnoj pozitivnoj korelaciji s uspjehom iz Matematike i Fizike. Činjenica da su faceti stavova prema matematici značajni prediktori uspjeha iz Matematike i Fizike ne iznenađuje. U prijašnjim istraživanjima s longitudinalnim nacrtima (House, 1995; Reynolds i Walberg, 1992b) utvrđeno je da stavovi prema matematici imaju snažan utjecaj na postignuće u matematici. Ma (1997) je pokazao kako su stavovi prema matematici i uspjeh iz matematike u recipročnom odnosu, uz razliku da je u njegovom modelu pozitivan odnos zabilježen između svih mjera stavova i uspjeha iz matematike. Također navodi kako uživanje u matematici izravno utječe na uspjeh, što se može usporediti s nalazom da je Naklonost prema matematici značajan prediktor uspjeha. Takvi nalazi imaju praktične implikacije posebice ako se uzme u obzir istraživanje koje sugerira da uspostavljeni negativni stavovi prema matematici jačaju tijekom vremena ( $M a, 2003$; Terwilliger i Titus, 1995).

Medijacijski efekt Naklonosti prema Matematici i Matematičkog samopoimanja u odnosu radnog pamćenja i uspjeha iz Matematike i Fizike ukazuje da bi se promjenom stava moglo utjecati na uspjeh iz Matematike i Fizike, neovisno o kapacitetu radnog pamćenja, za koji je utvrđeno da je snažan prediktor postignuća iz matematike. Istraživanja sugeriraju da je moguće koristiti različite oblike intervencija u tu svrhu. Zakaria, Chin i Daud (2010) pokazali su kako kooperativno učenje poboljšava postignuće i stavove prema matematici. Također, utvrđeno je i da motivacijski videofilmovi pozitivno utječu na stavove prema matematici (Hodges i Kim, 2013) kao i uvrštanje biografija matematičara tijekom podučavanja (Bidwell, 1993; Lit, Siu i Wong, 2001). Osim toga, socijalna potpora vršnjaka i profesora također ima značajnu ulogu u valenciji stavova prema matematici (Mata, Monteiro i Peixoto, 2012). Nadalje, medijacijski efekt Naklonosti prema matematici između Percipirane korisnosti matematike i uspjeha iz Matematike i Fizike ukazuje na važniju ulogu afekta u odnosu na instrumentalnu vrijednost. Taj se nalaz može dovesti u vezu s intrinzičnom i ekstrinzičnom motivacijom. Ryan i Deci (2000) navode kako se intrinzična motivacija odnosi na činjenje nečega jer je pojedincu zanimljivo ili ugodno, dok se ekstrinzična odnosi na činjenje nečega zbog ishoda te aktivnosti. Intrinzična motivacija rezultira kvalitetnim učenjem i kreativnošću te je posebno bitno obratiti pozornost na faktore koji je potiču ili umanjuju. Stoga ovaj nalaz navodi i na njegovanje intrinzične motivacije učenika u kontekstu matematike. Prema Teoriji Kognitivne Evaluacije (Ryan i Deci, 1985, prema Ryan i Deci, 2000) okolina koja stvara, održava i razvija intrinzičnu motivaciju uključuje interpersonalne događaje i strukture (poput nagrada ili povratnih informacija) koje stvaraju osjećaj kompetentnosti jer udovoljavaju psihološkim potrebama za kompetentnošću. U takvoj okolini povratne informacije popraćene su optimalnim izazovom, a omalovažavajuće evaluacije nisu prisutne. Autori također navode kako osjećaji kompetentnosti ne potiču razvoj 
intrinzične motivacije ukoliko nisu popraćeni osjećajem autonomije. Stoga je preporučeno učenicima omogućiti doživljavanje osjećaja autonomije koliko je moguće s obzirom na propisani kurikul i slobodno vrijeme na raspolaganju.

Rezultati provedenog istraživanja upućuju na daljnje provjere odnosa stavova prema matematici i uspjeha iz Matematike i Fizike, pogotovo jer je uzorak bio prigodan, relativno malen i pristran jer je moguće da se učenici V. gimnazije razlikuju u stavovima i kapacitetu radnog pamćenja od učenika ostalih srednjih škola. Prema tome, uzorak bi bio reprezentativniji kada bi bili uključeni učenici ostalih gimnazija i strukovnih škola. Osim toga, nema dovoljno istraživanja stavova prema matematici kod učenika osnovnih škola i studenata. Također, potrebna su još istraživanja usmjerenih na razjašnjavanje odnosa stavova prema matematici i radnog pamćenja. Koristan uvid pružila bi i longitudinalna istraživanja odnosa matematičkog samopoimanja s uspjehom iz matematike, pogotovo jer takvih podataka na hrvatskom uzorku nema, te istraživanja koja bi dala dublji uvid u razvoj matematičkog samopoimanja.

\section{ZAKUUČAK}

Svrha provedenog istraživanja bila je utvrditi odnos stavova prema matematici, radnog pamćenja i uspjeha iz Matematike i Fizike, pri čemu je uspjeh iz Matematike i Fizike zavisna varijabla. Analiza je pokazala kako kapacitet radnog pamćenja nije relevantan u prediktivnom modelu te kako su, usprkos značajnim korelacijama prije provedbe faktorske i regresijske analize, statistički značajni prediktori faceti stavova prema matematici Naklonost prema matematici i Matematičko samopoimanje, dok Percipirana korisnost matematike nije statistički značajan prediktor. Točnije, pokazalo se da su Naklonost prema matematici i Matematičko samopoimanje medijatori u odnosu kapaciteta radnog pamćenja i uspjeha iz Matematike i Fizike te da je Naklonost prema matematici medijator u odnosu Percipirane korisnosti matematike $\mathrm{i}$ uspjeha iz Matematike i Fizike. Takav nalaz ima praktične implikacije, a uz to navodi na daljnja istraživanja tih konstrukata, pogotovo razvoja stavova prema matematici i njihovog odnosa s uspjehom iz Matematike i Fizike.

\section{LITERATURA}

Aiken, L. R. i Dreger, R. M. (1974). The effect of attitude on performance in mathematics. Journal of Educational Psychology, 52(1), 19-24.

Antonnen, R. G. (1969). A longitudinal study in mathematics attitude. The Journal of Educational Research, 62(10), 467-471.

Arambašić, L., Vlahović-Štetić, V. i Severinac, A. (2005). Je li matematika bauk? Stavovi, uvjerenja i strah od matematike kod gimnazijalaca. Društvena istraživanja, 14(6), 1081-1102.

Ashcraft, M. H. i Kirk, E. P. (2001). The relationships among working memory, math anxiety, and performance. Journal of experimental psychology: General, 130(2), 224-237.

Ashcraft, M. H. i Krause, J. A. (2007). Working memory, math performance, and math anxiety. Psychonomic bulletin \& review, 14(2), 243-248.

Baron, R. M. i Kenny, D. A. (1986). The moderator-mediator variable distinction in social psychological research: Conceptual, strategic and statistical considerations. Journal ofPersonality and Social Psychology, 51(6), 1173-1182.

Bidwell, J. K. (1993). Humanize your classroom with the history of mathematics. The Mathematics Teacher, 86(6), 461-464.

Biggs, J. B. (1959). The teaching of mathematics: II - Attitudes to arithmetic number anxiety. Educational Research, 1, 6-21. 
Blair, G., Cooper, J., Coppock, A., Humphreys, M., Sonnet, L. i Fultz, N. (2019). Fast Estimators for Design-Based Inference. Preuzeto s https://cran.r-project.org/web/packages/estimatr/index. html

Briggs, S. R. i Cheek, J. M. (1986). The role of factor analysis in the development and evaluation of personality scales. Journal of personality, 54(1), 106-148.

Bull, R., i Lee, K. (2014). Executive functioning and mathematics achievement. Child Development Perspectives, 8(1), 36-41.

Bull, R. i Scerif, G. (2001). Executive functioning as a predictor of children's mathematics ability: Inhibition, switching, and working memory. Developmental neuropsychology, 19(3), 273-293.

Champely, S. (2018). pwr: Basic Functions for Power Analysis. R package version 1.2-2. Preuzeto S https://CRAN.R-project.org/package=pwr.

Cowan, N. (2010). The Magical Mystery Four: How is Working Memory Capacity Limited, and Why? Current Directions in Psychological Science, 19(1), 51-57.

Dutton, W. H. (1954). Measuring attitude toward arithmetic. Elementary School Journal, 55(1), 2431.

Eshun, B. (2004). Sex-differences in attitude of students towards mathematics in secondary school. Mathematics Connection, 4, 1-13.

Friso-van den Bos, I., Van der Ven, S. H., Kroesbergen, E. H. i Van Luit, J. E. (2013). Working memory and mathematics in primary school children: A meta-analysis. Educational research review, 10, 29-44.

Gallagher, A. M. i De Lisi, R. (1994). Gender differences in Scholastic Aptitude Test: Mathematics problem solving among high-ability students. Journal of Educational Psychology, 86(2), 204-211.

Haladyna, T., Shaughnessy, J. i Shaughnessy, J. M. (1983). A causal analysis of attitude toward mathematics. Journal for Research in Mathematics Education, 14(1), 19-29.

Hodges, C. B. i Kim, C. (2013). Improving College Students' Attitudes toward Mathematics. TechTrends: Linking Research and Practice to Improve Learning, 57(4), 59-66.

Holmes, J. i Adams, J. W. (2006). Working memory and children's mathematical skills: Implications for mathematical development and mathematics curricula. Educational Psychology, 26(3), 339366.

Hothorn, T., Zeileis, A., Farebrother, R. W., Cummins, C., Millo, G. i Mitchell, D. (2018). Testing Linear Regression Models. Preuzeto s https://cran.r-project.org/web/packages/Imtest/index.html.

House, J.D. (1995). The predictive relationship between academic self-concept, achievement expectancies, and grade performance in college calculus. The Journal of Social Psychology, 135(1), 111-112.

Hutton, U. M. Z. i Towse, J. N. (2001). Short-term memory and working memory as indices of children's cognitive skills. Memory, 9(4), 383-394.

Imbo, I., Vandierendonck, A. i Vergauwe, E. (2007). The role of working memory in carrying and borrowing. Psychological Research, 71(4), 467-483.

Jung, E. S. i Reid, N. (2009). Working memory and attitudes. Research in Science \& Technological Education, 27(2), 205-223.

Korkmaz, S., Goksuluk, D. i Zararsiz, G. (2014) MVN: An R Package for Assessing Multivariate Normality. The R Journal. 6(2), 151-162.

LeBlanc, M. D. i Weber-Russell, S. (1996). Text integration and mathematical connections: A computer model of arithmetic word problem solving. Cognitive Science, 20(3), 357-407.

Leder, G. i Grootenboer, P. (2005). Affect and mathematics education. Mathematics Education Research Journal, 17(2), 1-8.

Lit, C.-K., Siu, M.-K. i Wong, N.-Y. (2001). The use of history in the teaching of mathematics: Theory, practice, and evaluation of effectiveness. Educational Journal, 29(1), 17-31.

Ma, X. (1997). Reciprocal relationships between attitude toward mathematics and achievement in mathematics. The Journal of Educational Research, 90(4), 221-229.

$\mathrm{Ma}$, X. (2003). Effects of early acceleration of students in mathematics on attitudes toward mathematics and mathematics anxiety. Teachers College Record, 105(3), 438-464. 
Josip Novak, Predrag Brođanac

Ma, X. i Kishor, N. (1997). Assessing the relationship between attitude toward mathematics and achievement in mathematics: A meta-analysis. Journal for Research in Mathematics Education, 28(1), 26-47.

Mata, M. D. L., Monteiro, V. i Peixoto, F. (2012). Attitudes towards mathematics: Effects of individual, motivational and social support factors. Child Development Research. Preuzeto s https:// www.hindawi.com/journals/cdr/2012/876028/

Majeed, A. A., Darmawan, I. G. N. i Lynch, P. (2013). A confirmatory factor analysis of attitudes toward mathematics inventory (ATMI). The Mathematics Educator, 15(1), 121-135.

McLeod, D. B. (1992). Research on affect in mathematics education: A reconceptualisation. U: D. A. Grouws (ur.), Handbook of research on mathematics learning and teaching, 575-596. New York, NY: Macmillan.

Metsämuuronen, J. (2012). Challenges of the Fennema-Sherman test in the international comparisons. International Journal of Psychological Studies, 4(3), 1-22.

Neale, D. (1969). The role of attitudes in learning mathematics. The Arithmetic Teacher, 16(8), 631641.

Novak, J. (2018). Odnos radnog pamćenja, ispitne anksioznosti, savjesnosti, socioekonomskog statusa i školskog uspjeha. Napredak: časopis za pedagogijsku teoriju i praksu, 159(4), 479-504.

Pavlin-Bernardić, N., Vlahović-Štetić, V., Rovan, D. i Arambašić, L. (2009). Stavovi, uvjerenja i strah od matematike kod učenika osnovne škole. U: D. Ljubotina, Ž. Kamenov, U. Mikac i D. Urch, (ur.), 19. Dani Ramira i Zorana Bujasa: Program i sažeci priopćenja, (82-82.). Zagreb: Školska knjiga.

Poffenberger, T. i Norton, D. (1959). Factors in the formation of attitudes toward mathematics. Journal of Educational Research, 52(5), 171-176.

R Core Team (2019). R: A Language and Environment for Statistical Computing. R Foundation for Statistical Computing, Vienna.

Revelle, W. (2019). psych: Procedures for Personality and Psychological Research, Northwestern University, Evanston, Illinois, USA. Preuzeto s https://cran.r-project.org/web/packages/psych/ index.html

Reynolds, A. J. i Walberg, H. J. (1992a). A structural model of science achievement and attitude: An extension to high school. Journal of Educational Psychology, 84(3), 371-382.

Reynolds, A.J. i Walberg, H.J. (1992b). A process model of mathematics achievement and attitude. Journal for Research in Mathematics Education, 23(4), 306-328.

Ryan, R. M. i Deci, E. L. (2000). Intrinsic and Extrinsic Motivations: Classic Definitions and New Directions. Contemporary Educational Psychology, 25(1), 54-67.

Seyler, D. J., Kirk, E. P. i Ashcraft, M. H. (2003). Elementary subtraction. Journal of Experimental Psychology: Learning, Memory, and Cognition, 29(6), 1339-1352.

Shashaani, L. (1995). Gender differences in mathematics experience and attitude and their relation to computer attitude. Educational Technology, 35(3), 32-38.

Stone, J. i Towse, J. (2015). A working memory test battery: Java-based collection of seven working memory tasks. Journal of Open Research Software, 3(1), e5.

Swanson, H. L. i Beebe-Frankenberger, M. (2004). The relationship between working memory and mathematical problem solving in children at risk and not at risk for serious math difficulties. Journal of Educational Psychology, 96(3), 471-491.

Terwilliger, J. S. i Titus, J. C. (1995). Gender differences in attitudes and attitude changes among mathematically talented youth. Gifted Child Quarterly, 39(1), 29-35.

Tuohilampi, L., Hannula, M. S., Laine, A. i Metsämuuronen, J. (2014). Examining mathematics-related affect and its development during comprehensive school years in Finland. U: S. Oesterle, P. Liljedahl, C. Nicol i D. Allan (ur.), Proceedings of the 27th conference of the International Group for the Psychology of Mathematics Education (Vol. 3, str. 281-288). Vancouver, Canada: PME.

Wilson, K. M. i Swanson, H. L. (2001). Are mathematics disabilities due to a domain-general or a domain-specific working memory deficit?. Journal of Learning disabilities, 34(3), 237-248.

Yap, B.W i Sim, C.H. (2011). Comparisons of various types of normality tests. Journal of Statistical Computation and Simulation. 81, 2141-2155. 
Zakaria, E., Chin, L. C. i Daud, M. Y. (2010). The Effects of Cooperative Learning on Students' Mathematics Achievement and Attitude toward Mathematics. Journal of Social Sciences, 6(2), 272275.

\title{
Which is a Better Predictor of Achievement in Mathematics and Physics - Attitudes towards Mathematics or Working Memory Capacity?
}

\begin{abstract}
Prior research have shown that attitudes toward mathematics are significant predictors of different outcomes related to mathematics, such as engagement or achievement, but also of later academic performance in mathematics and science, as well as success and persistence in learning of mathematics. However, attitudes toward mathematics and their relationship with achievement in Mathematics and Physics, together with potential role of working memory in the mentioned relationship are underresearched on Croatian samples. Working memory is strongly related to mathematics performance and it is therefore of practical significance to determine its role in relationship between attitudes towards mathematics and achievement in Mathematics and Physics. The research was conducted on a convenient sample which consisted of 178 students from the 5th Gymnasium in Zagreb, which had balanced ratio of sexes. Results of this research suggest that working memory and perceived usefulness of mathematics are not significant predictors of achievement in Mathematics and Physics after Liking Mathematics and Mathematics self-concept were included in the regression equation. The final model and registered mediational effects have practical implications and entice further research on the relationship among these constructs.
\end{abstract}

Keywords: attitudes towards mathematics, working memory, school achievement

\section{Was ist ein besserer Prädiktor für den Lernerfolg in Mathematik und Physik - Einstellungen zur Mathematik oder die Arbeitsgedächtniskapazität?}

Zusammenfassung: Untersuchungen haben gezeigt, dass die Einstellungen zur Mathematik ein wichtiger Prädiktor unterschiedlicher Ergebnisse im Fach Mathematik sind, z. B. im Hinblick auf das Engagement oder den Lernerfolg, aber auch auf die spätere akademische Leistung in Mathematik und naturwissenschaftlichen Fächern sowie im Hinblick auf den Erfolg und die Zielstrebigkeit beim Mathematiklernen. Allerdings gibt es nur wenige Untersuchungen über die Einstellungen kroatischer Schüler zur Mathematik und ihr Verhältnis zum Lernerfolg in Mathematik und Physik sowie über die Rolle des Arbeitsgedächtnisses in diesem Verhältnis. Das Arbeitsgedächtnis ist stark verbunden mit der Leistung in Mathematikaufgaben. Dementsprechend ist die Bestimmung der Rolle, die die Einstellungen zur Mathematik im Verhältnis zum Lernerfolg in Mathematik und Physik hat, von praktischem Nutzen. Die Untersuchung wurde auf einem entsprechenden Muster von 178 Schülern des V. Gymnasiums in Zagreb durchgeführt, unter denen Schüler beider Geschlechter gleichmäßig vertreten sind. Die Ergebnisse dieser Untersuchung zeigen, dass das Arbeitsgedächtnis und die wahrgenommene Nützlichkeit von Mathematik keine bedeutenden Prädiktoren des Lernerfolgs in Mathematik und Physik darstellen, wenn in der Regressionsgleichung auch der Aspekt der Neigung zur Mathematik und der Aspekt der Selbsteinschätzung der mathematischen Fertigkeiten als Aspekte der Einstellungen zur Mathematik vertreten sind. Das endgültige Modell und die verzeichneten Mediationseffekte haben praktische Auswirkungen und verweisen auf weitere Untersuchungen des Verhältnisses dieser Konstrukte.

Schlüsselwörter: Einstellungen zur Mathematik, Arbeitsgedächtnis, Lernerfolg 